\title{
The Chairman's Annual Report for the Year 1971-1972
}

The past year has marked an important stage in the development of the Society's activities in the field of Byelorussian culture. Our steady progress has coincided with what appears to be a growing interest in Byelorussia among historians and scholars in the West. Independently of the Society's continuing good relations with libraries and cultural institutions in Eastern Europe, contacts have been made with a number of Slavists engaged in research into Byelorussian studies in the United States and Israel, some of whom are already contributing articles to the Society's Journal. There is every hope that further contacts and exchanges will take place during the coming year.

During the past session two new members have joined the Society: Mr Alaksiej Cytovic of Marian House, North Finchley, who is known for his work on the archives of the Pinsk vicariate, and Mme Susan Picarda, wife of the Honorary Secretary.

The Society's budget during the past year was satisfactory. The total income from subscriptions, grants and sales as on the 4th February amounted to $£ 930$, whereas expenditure, including the cost of publications, lectures and postage did not exceed $£ 901$, leaving a net surplus for the year of $£ 29$.

A further two numbers of the Journal of Byelorussian Studies were published during the session (Vol. II No. 2 for the year 1970, and Vol. II No. 3 for the year 1971), and the final number of the second volume (Vol. II No. 4 for the year 1972) has already gone to press. It will appear towards the end of the autumn. The Editorial Board is made up as follows: Mr James Dingley (Editor), Dr Arnold McMillin, Revd. A. Nadson and Mr Guy Picarda.

Once again the Society organised an annual lecture course on Byelorussian history and culture at the Society of Antiquaries of London, Burlington House, Piccadilly W.1., the sixth in the present series. As in the past six lectures were read, all of which took place in the Antiquaries lecture hall. On the 24th November Dr Arnold McMillin delivered a lecture, postponed from the previous session, on "Alhierd Abuchovič (1840-1898) and his times". Mr James Dingley addressed the Society on the "Gramatyka Slovenskaja of Jan Uževič (1643, 1645)" on the 14th December 1971. "The Monastery of Laūryšava and its Gospels (early 14th century)" was the subject of a paper illustrated with slides by Revd. Alexander Nadson on the 5th February 1972. On the 5th March the Rt. Revd. Ceslaus Sipovič, Bishop of Mariamme, gave a lecture on "Archimandrite Andrej Cikota (1891-1952) and his place in the Byelorussian Catholic Revival". Owing to an unexpected personal commitment the Hon. Secretary was obliged to postpone his lecture on Byelorussian 
dietetics until the following session, but Revd. Alexander Nadson kindly agreed at short notice to address the Society in his stead on the 25th April. The subject of his talk was "The prayer-book of Francis Skaryna (1522)". Finally on the 23rd May, Dr Richard A. French read a paper on "Present population trends in Byelorussia", illustrated with graphs and slides. Attendance varied between 31 and 20 members and visitors.

The Council met on the 22nd March 1972 to deal with the ordinary business and activity of the Society.

The Council is confident that the coming year will see a further development in the activities of the Society, and a growing interest in our work.

Dated in London 31st July 1972. 